\title{
ACESSIBILIDADE COMO CRITÉRIO DE QUALIDADE DO ESPAÇO TURÍSTICO: ESTUDO DE CASO DA ÁREA CENTRAL DE BALNEÁRIO CAMBORIÚ-SC
}

ACCESSIBILITY AS A QUALITY CRITERA OF THE TOURISM SPACE: A CASE STUDY OF THE CEDNTRAL AREA OF BALNEÁRIO CAMBORIÚ-SC

\section{LA ACCESIBILIDAD COMO CRITERIO DE CALIDAD DEL ESPACIO TURISTICO: ESTUDIO DE CASO DEL ÁREA CENTRAL DE BALNEÁRIO CAMBORIÚ-SC}

\section{Josildete Pereira de Oliveira}

Universidade do Vale do Itajaí

Docente e pesquisadora do Programa de Pós-Graduação em Turismo e Hotelaria da Universidade do Vale do Itajaí. Doutora em Geografia pela Université de Caen Basse Normandie Balneário Camboriú, Santa Catarina, Brasil joliveira@univali.br

\section{Letícia Indart Franzen}

Universidade Federal do Rio Grande Docente nos cursos de Turismo, Hotelaria e Tecnologia em eventos da Universidade Federal do Rio Grande Santa Vitória do Palmar, Rio Grande do Sul, Brasil leticiaifranzen@gmail.com

\section{Bruna Górski Varella}

Graduada em Arquitetura e Urbanismo pela Universidade do Vale do Itajaí Balneário Camboriú, Santa Catarina, Brasil brunagorski@yahoo.com.br 
RESUMO: O presente estudo centraliza suas discussões na acessibilidade aos espaços públicos de uso turístico das cidades para pessoas com mobilidade reduzida e com deficiência. $\mathrm{O}$ artigo tem como objetivo principal analisar a acessibilidade após a requalificação urbana da área central da cidade de Balneário Camboriú/SC (importante destino turístico do litoral brasileiro), considerando as adaptações necessárias estabelecidas nas leis e nas normativas para pessoas com mobilidade reduzida e com deficiência. Para tanto, busca-se relacionar os conceitos de espaço turístico urbano e acessibilidade, por meio de uma pesquisa bibliográfica, formando assim um referencial teóricoconceitual. Além disso, foi realizada uma análise qualitativa de caráter exploratória e descritiva, buscando mapear a acessibilidade do espaço turístico e dos equipamentos dessa área da cidade, ressaltando as áreas que passaram pela requalificação urbana recente. Em seguida, foram realizadas a sistematização e a análise dos dados coletados, correlacionando-os com o referencial teóricoconceitual. Os resultados indicam que a qualidade do espaço turístico urbano da cidade, no que se refere à acessibilidade, ainda não se apresenta de forma completa e contínua, não garantindo autonomia e independência à pessoa com mobilidade reduzida e com deficiência. Concluiu-se, dessa forma, que as requalificações urbanas recentes não foram executadas na totalidade como recomenda a NBR9050, para promover rotas acessíveis e inclusão ao espaço urbano.

PALAVRAS-CHAVE: Acessibilidade, Morfologia, Espaço Turístico.

ABSTRACT: This study focuses on the accessibility of public spaces of the city for tourist use by people with limited mobility or disabilities. The article analyzes accessibility following the urban redevelopment of the central area of Balneario Camboriú/SC (a major tourism destination on the coast of the South of Brazil), considering the necessary adaptations for people with reduced mobility and disabilities established in the laws and regulations. This study seeks to relate the concepts of urban tourist space and accessibility, through a literature review, thus forming a theoretical and conceptual framework. A qualitative analysis of an exploratory and descriptive nature was conducted, to map the accessibility of the touristic space and the facilities of this area of the city, highlighting the areas that have recently undergone urban redevelopment. Next, a systematization and analysis of the collected data was carried out, correlating them with the theoretical and conceptual framework. The results indicate that in terms of accessibility, the quality of the urban touristic space of the city, is still not complete and continuous, and does not guarantee autonomy and independence for people with reduced mobility and disabilities. It is therefore concluded that the urban adaptations were not fully executed in accordance with NBR9050, and do not fully promote accessible routes for these people, and their inclusion in the urban space.

KEYWORDS: Accessibility; Morphology; Area of Interest.

RESUMEN: El presente estudio centraliza sus discusiones en la accesibilidad a los espacios públicos de uso turístico de las ciudades para personas con movilidad reducida y con discapacidad. El artículo tiene como principal objetivo analizar la accesibilidad tras la recalificación urbana del área central de la ciudad de Balneário Camboriú/SC (importante destino turístico de la costa brasileña), considerando las adaptaciones necesarias establecidas en las leyes y en las normas para personas con movilidad reducida y con discapacidad. Para ello se intentó relacionar los conceptos de espacio turístico urbano y accesibilidad por medio de una investigación bibliográfica, formando así un referente teórico conceptual. Además, fue realizado un análisis cualitativo de carácter exploratorio y descriptivo, 
buscando mapear la accesibilidad del espacio turístico y de los equipamientos de esa área de la ciudad, destacando las áreas que pasaron por la recalificación urbana reciente. A continuación se realizó la sistematización y el análisis de los datos recogidos, correlacionándolos con el referente teórico conceptual. Los resultados indican que la calidad del espacio turístico urbano de la ciudad, en lo que se refiere a la accesibilidad, aún no se presenta de forma completa y continua, y no garantiza autonomía e independencia a la persona con movilidad reducida y con deficiencia. De esta manera se concluye que las recalificaciones urbanas recientes no fueron ejecutadas en su totalidad, como recomienda la NBR9050, para promover rutas accesibles e inclusión en el espacio urbano.

PALABRAS CLAVE: Accesibilidad; Morfología; Espacio Turístico.

\section{INTRODUÇÃO}

\section{CONTEXTUALIZAÇÃO DO TEMA}

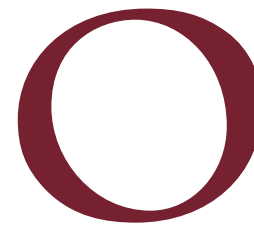

turismo como atividade econômica e fenômeno social vem apresentando, nos últimos tempos, um crescimento e um desenvolvimento de suas atividades de forma ascendente. Cada vez mais, novos destinos turísticos vêm se consolidando no Brasil e no mundo, tornando-se mais difícil a inserção no mercado altamente competitivo do turismo. Frente a este contexto, os destinos turísticos devem começar a planejar suas ações considerando o intuito de se posicionar no mercado como um destino diferenciado, capaz de atrair turistas de diversas partes do mundo, aumentando assim o seu ciclo de vida sem que para isso deixe de considerar os anseios da comunidade que irá receber os turistas que ali chegam (Ruschmann, 1997).

Os turistas, ao visitarem uma cidade, seja por qualquer motivação, pretendem se deslocar por ela, para isso necessitam que a cidade esteja organizada, bem sinalizada, com informações legíveis, bem iluminada, para que possa deslocarse por ela sem riscos de se perder, de ser assaltado, entre outros acontecimentos negativos gerados por falta de informação precisa (Grinover, 2007).

A acessibilidade nos espaços públicos está pautada na premissa de que todos os cidadãos tenham o livre acesso a esses ambientes, porém existem públicos que possuem certas limitações no que diz respeito ao seu deslocamento. Essas limitações dificultam o acesso a determinados equipamentos e espaços públicos, como as calçadas, os parques, as praças, etc. 
Este artigo é um extrato da pesquisa realizada sobre o tema, cujo objetivo principal foi analisar a acessibilidade após a requalificação urbana da área central da cidade de Balneário Camboriú/SC, considerando as adaptações necessárias estabelecidas nas leis e nas normativas para pessoas com mobilidade reduzida e com deficiência. Para tanto, buscou-se relacionar os conceitos de espaço turístico urbano e acessibilidade, por meio de uma pesquisa bibliográfica, formando assim um referencial teórico-conceitual. Além disso, foi realizada uma análise qualitativa de caráter exploratória e descritiva, pesquisa de campo com o mapeamento da acessibilidade do espaço turístico e dos equipamentos dessa área da cidade, ressaltando as áreas que passaram pela requalificação urbana recente. Durante a pesquisa de campo foi realizado o levantamento fotográfico. Desta forma, o problema colocado por essa pesquisa foi: como se verifica a acessibilidade após a requalificação urbana da área central de Balneário Camboriú, para pessoas com mobilidade reduzida e com deficiência dos espaços turísticos, considerando a acessibilidade como critério de qualidade do espaço turístico onde o turismo é atividade consolidada?

Para a verificação da acessibilidade, foi realizado um mapeamento dos trechos selecionados realizado por meio de pictogramas criados por Franzen (2014) e Franzen e Oliveira (2015), que na pesquisa representou a acessibilidade em três diferentes contextos: acessibilidade total, acessibilidade parcial e inacessibilidade. Neste estudo, foram utilizados os pictogramas de Franzen (2014, 2015), porém a acessibilidade foi classificada em: integral, próxima à integral, parcial e reduzida.

A adaptação dos espaços públicos é importante tanto para quem visita quanto para quem é visitado, pois estes ambientes são caracterizados como local de convívio em sociedade, de socialização, de desfrute. Além de ser uma necessidade, é obrigação que a administração pública planeje os ambientes considerando as limitações do público com necessidades especiais. Tais ambientes, ao estarem adaptados para os deficientes e as pessoas com mobilidade reduzida, estarão moldados para que qualquer pessoa possa circular com autonomia e segurança. Assim como os espaços públicos, os espaços públicos de lazer também devem seguir este princípio, dinamizando e 
aumentando a oferta de lazer da cidade tanto para a população local quanto para os visitantes deficientes e com mobilidade reduzida.

A escolha pela cidade de Balneário Camboriú se deve à sua importância no cenário do turismo nacional. O Índice de Competitividade do Turismo Regional - 65 Destinos Indutores do Desenvolvimento Turístico Regional, elaborado pelo Ministério do Turismo e que se iniciou em 2007 a fim de medir a competitividade de destinos turísticos e monitorar sua evolução, identificou a cidade de Balneário Camboriú como um dos Destinos Indutores de Santa Catarina. Além de seu destaque nacional, a cidade vem sofrendo requalificações urbanas desde 2010 com o objetivo de melhorar a acessibilidade da cidade, tornando-a estudo de caso pertinente.

\section{APORTE TEÓRICO-CONCEITUAL}

\section{ESPAÇO TURÍSTICO URBANO}

O espaço turístico, de forma ampla, pode ser classificado em dois tipos, o espaço natural (adaptado ou virgem) e o espaço urbano. O espaço natural adaptado é composto atualmente pela zona rural das cidades, onde ocorrem as produções agrícolas e agropecuárias, onde acontecem intervenções do homem, ou seja, as matas são inseridas como e onde o ser humano deseja (Boullón, 2002). O mesmo ocorre nos espaços litorâneos, hoje transformados e, em muitos lugares, totalmente destruídos por causa das constantes modificações estabelecidas pelo ser humano com o uso e a ocupação provocada pela urbanização. Dessa forma, a ocupação urbana alterou completamente o espaço natural litorâneo, transformando-o em espaço construído (Santos Júnior, 2012).

O ser humano, ao longo de sua trajetória histórica e cultural, vem se apropriando do espaço natural onde está inserido, dando-lhe forma e significado cultural de acordo com as suas necessidades e anseios (Santos, 1997; Boullón, 2002). Com o passar do tempo, aquela paisagem, que era estritamente natural e sem nenhuma intervenção humana, pode acabar passando por constantes processos de artificialização, dando forma e 
estabelecendo funções de uma paisagem urbana. Em alguns casos, a urbanização rápida, desmedida e desenfreada pode causar danos irreversíveis, com problemas urbanísticos e ambientais.

A paisagem urbana pode ser compreendida como um complexo mosaico de elementos físicos e biológicos com uma matriz de infraestrutura e organização social, que reflete o grau de urbanização impresso pela sociedade que ali predomina, de acordo com os condicionamentos do sítio urbano (Alberti, 2005).

O espaço urbano, também chamado de artificial, é formado exclusivamente pela ação humana, é ela que dá forma e significado à paisagem onde está inserida, a formação deste espaço está intimamente ligada à questão social, visceral para a existência humana. O homem, por caracteriza-se como um ser histórico, ao transformar o espaço dá-lhe características temporais representativas de significados próprios para aquela época. O tempo exerce a importante função de dinamizar a formação espacial daquele espaço. Espaço, tempo e sociedade formam juntos uma importante trilogia para que se possa entender a formação espacial que as cidades apresentam atualmente. O espaço urbano é fruto da ação humana em um determinado tempo (Gayer, 2006).

O espaço é uma representação de uma sociedade, é histórico, pois está inserido em um processo constante de evolução social que não possui fim. Dessa forma, entende-se que o espaço caracteriza uma sociedade, pois é nele onde a sociedade se expressa, esculpe seus hábitos, manifestações e costumes. A cultura do ser humano inserido em certo espaço também é um dos fatores que determinam a maneira como uma sociedade se apropria daquele espaço.

Deve-se entender que a atividade turística pode ocorrer tanto no espaço urbano quanto no espaço natural adaptado. Para que ocorra tanto em um quanto no outro deve haver condições espaciais essenciais para seu desenvolvimento com qualidade e de forma ordenada. Neste sentido, Boullón (2002, p. 79), ao discorrer sobre esta questão, expõe que "o espaço turístico é consequência da presença e distribuição territorial dos atrativos 
turísticos [...]. Este elemento do patrimônio turístico, mais o empreendimento e a infraestrutura turísticas, são suficientes para definir o espaço turístico de qualquer país".

A existência de atrativos turísticos é o que condiciona uma cidade ser uma cidade turística, ou seja, "a existência do espaço turístico está condicionada à presença de atrativos turísticos" (Boullón, 2005, p. 30) Nesse sentido, Santos Júnior (2012) afirma que tais atrativos turísticos podem ser de cunho climático, geomorfológico e histórico-cultural. Em se tratando da atividade turística, Balneário Camboriú pode ser classificada, segundo Boullón (2002), como um centro turístico de distribuição, ou seja: um conglomerado urbano que serve de base para o turista e que, após a visita aos atrativos localizados em seu raio de influência, os turistas retornam para dormir e utilizar os serviços básicos, principalmente durante a noite.

A cidade de Balneário Camboriú tem seu turismo baseado na categoria de Turismo de Sol e Praia. A extrema sazonalidade desta modalidade, resultante das estações de calor e frio, tem impulsionado as cidades a criarem estratégias para atrair os turistas fora de temporada, como eventos e exploração do ecoturismo e do turismo cultural.

A sinalização viária é fundamental para orientar o turista. Deve proporcionar informação necessária para seu deslocamento e indicar-lhe os detalhes que podem ser apreciados em seus percursos e mirantes (Boullón, 2002). Portanto, para o turista com capacidade reduzida, é importante que exista uma infraestrutura e um espaço turístico adequado para suas necessidades, para que possa locomover-se e participar das atividades sem discriminação. Este público diferenciado, crescente no mercado a cada ano, optará por uma cidade acessível na escolha de destinos para suas viagens e alojamentos.

A promoção do turismo, atração de investimentos, planejamento e fiscalização, é de responsabilidade do Poder Público (Dias, 2005). Em Balneário Camboriú a construção do passeio cabe ao proprietário privado, porém cabe ao poder público garantir a padronização e a acessibilidade do espaço público por meioda fiscalização, para que a infraestrutura da cidade esteja adequada ao turista com capacidade de locomoção reduzida. 


\section{ACESSIBILIDADE PARA PESSOAS COM MOBILIDADE REDUZIDA E PARA DEFICIENTES}

Vários são os estudos relacionados à acessibilidade e à inclusão. De acordo com Sassaki (1997,) os deficientes passaram por quatro fases diferentes de evolução no mercado de trabalho até conseguir seu lugar na sociedade. Essas fases foram denominadas por ele como: a fase da exclusão, da segregação, da integração e, atualmente, a fase da inclusão. A primeira fase foi caracterizada pela total falta de acesso por parte dos deficientes ao mercado de trabalho. Alguns anos depois esse pensamento mudou razoavelmente, contudo os deficientes ainda não conseguiam se inserir no mercado competitivo, muito menos eram considerados cidadãos com direitos e deveres perante a sociedade. Como se pode perceber, os deficientes dificilmente eram incluídos em seu ambiente de trabalho, as infraestruturas não estavam adaptadas, não proporcionavam a autonomia e a segurança para esses colaboradores trabalharem com dignidade e competência. A inclusão social das pessoas com deficiência demorou a ocorrer tanto no Brasil quanto em outras partes do mundo. A fase da inclusão é a mais recente das quatro fases definidas por Sassaki (1997, p. 73).

Silva e Boia (2006, p. 12) citam que existem atualmente 7 (sete) princípios da inclusão, definidos anteriormente por Ross (1998) como: celebração das diferenças sem rótulos ou preconceitos; direito de decidir e tomar decisões; valorização da diversidade humana; direito de contribuir com sua experiência; promoção do aprendizado cooperativo; promoção da solidariedade humana; valorização da cidadania e da qualidade de vida.

A inclusão deve ser realizada em todas as esferas, as leis devem conter os direitos e os deveres em todos os âmbitos, deve garantir o acesso das pessoas com deficiência e com mobilidade reduzida em todos os lugares, em todos os aspectos, sejam eles à informação, ao lazer, à moradia, ao trabalho, etc., sem que para isso fosse pensado que algo estava sendo feito por bondade, por caridade ou por pena, "[...] ao contrário, é uma ação entre cidadãos responsáveis pela qualidade de vida de outros cidadãos" (Silva \& Boia, 2006, p. 12). 
Em relação ao turismo, a inclusão social dos deficientes e das pessoas com mobilidade reduzida deve ser pensada quando ocorre o planejamento dos serviços e dos espaços turísticos ou não turísticos. Todos os serviços e os espaços devem estar ao alcance de todas as pessoas, independente de sua condição física, mental, sensorial, financeira, etc.

No destino turístico, para que ocorra inclusão deste público aos espaços urbanos e públicos, deve haver acessibilidade, ou seja, acesso livre com autonomia e segurança em todos os espaços de circulação por todos os cidadãos, devendo haver adaptações específicas, sem que para isso haja separação ou segregação, conforme o exposto anteriormente. Neste caso, é importante que os profissionais envolvidos tenham uma visão profissional, considerando instrumentos como a norma da ABNT 9050 e demais leis e normativas a respeito.

A norma 9050 da Associação Brasileira de Normas Técnicas (ABNT), "Acessibilidade a edificações, mobiliário, espaços e equipamentos urbanos", foi criada em 1985, revisada em 1994 e por último em 2004. Esta norma tem por objetivo "estabelecer critérios e parâmetros técnicos a serem observados quando do projeto, construção, instalação e adaptação de edificações, mobiliário, espaços e equipamentos urbanos às condições de acessibilidade". (NBR 9050 2004, p. 1).

Estes parâmetros são estabelecidos para calçadas, rebaixamento de calçadas, rampas, escadas, faixas de pedestre, semáforos, orelhões, bancos, chuveiros, estacionamentos, entre outros, elementos que compõem o espaço público e proporcionam a acessibilidade e a autonomia de pessoas com capacidade reduzida. Segundo a NBR 9050, uma rota é considerada acessível quando os elementos morfológicos deste trajeto, que proporcionam e auxiliam no deslocamento, estão de acordo com seus parâmetros técnicos. Portanto, as rotas acessíveis devem possuir passeios com pisos de superfície regular e antiderrapante, a fim de evitar trepidação em dispositivos com rodas. Desníveis devem ser evitados, inclusive as tampas de caixas de inspeção e de visita situadas na faixa de circulação devem estar absolutamente niveladas com o piso. As faixas livres de circulação de pedestres devem ser completamente desobstruídas e isentas de interferências, com largura 
ISSN: 1983-7151

mínima recomendável de 1,50m e mínima admissível de 1,20m, e altura livre mínima de 2,10 m. A sinalização tátil direcional deve ser utilizada para indicar o caminho a ser percorrido. Quando houver mudança de direção, deve haver uma área de alerta indicando que existem alternativas de trajeto (figura 01).

Figura 1 - Modulação de Piso e Composição de sinalização tátil de alerta e direcional

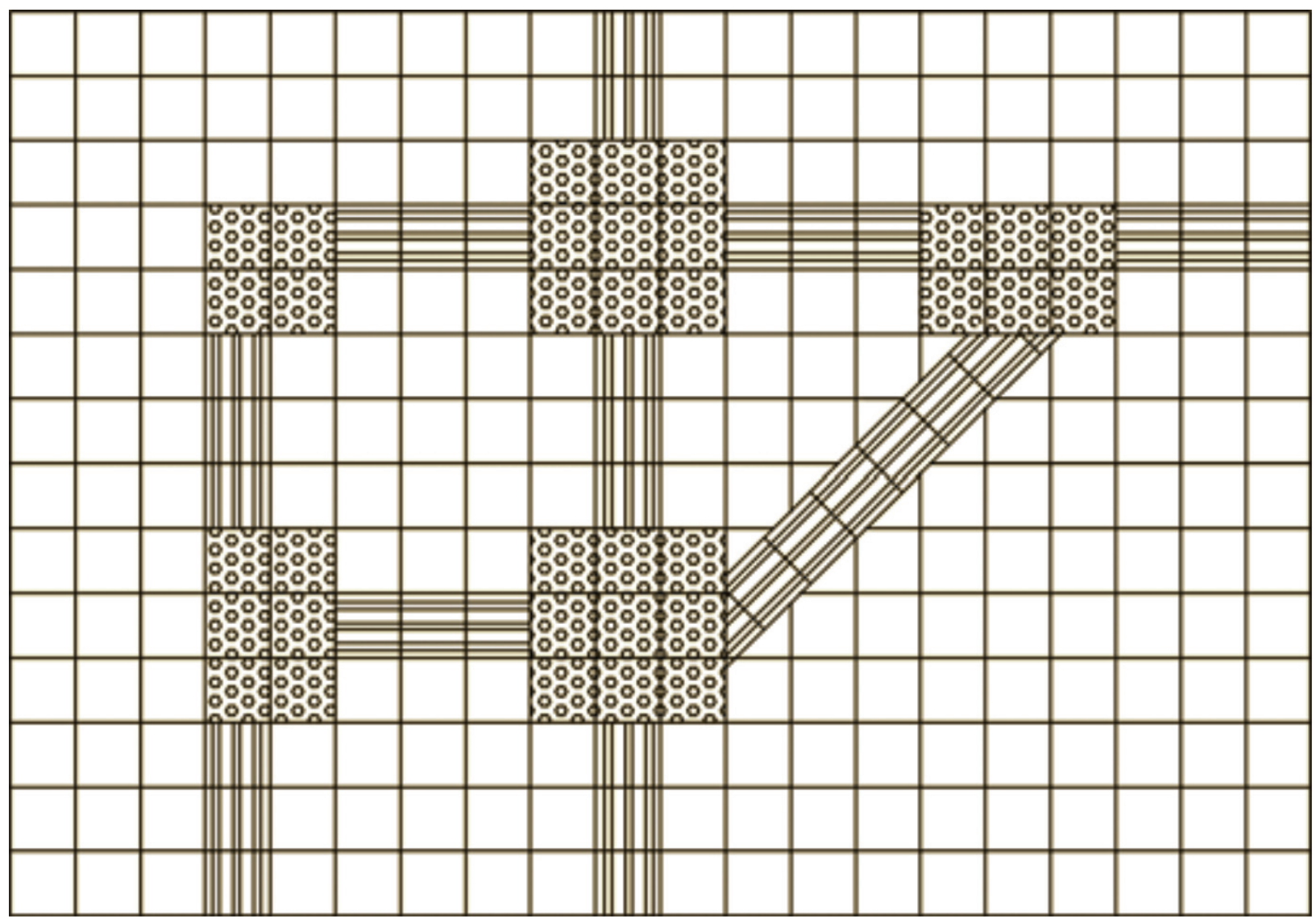

Fonte: NBR 9050, 2004, p. 31, 34 e 35.

As calçadas devem ser rebaixadas junto às travessias de pedestres, conforme indica a figura 02 , sem que haja desnível entre o término do rebaixamento da calçada e o leito carroçável, e devem ser adequadamente sinalizadas com o símbolo internacional do acesso e o piso tátil de alerta. Quando houver sinalização tátil direcional no passeio, este deve encontrar com a sinalização tátil de alerta. Os rebaixamentos das calçadas localizados em lados opostos da via devem estar alinhados entre si, a inclinação deve ser constante e não superior a 8,33\% e a largura mínima de 1,20m. Além disso, deve garantir uma faixa livre no passeio de $0,80 \mathrm{~m}$, sendo recomendado $1,20 \mathrm{~m}$. Os estudos de Vieira e Morastoni (2013), relacionados à acessibilidade e à mobilidade das calçadas, apontam os Índices de Caminhabilidade (IC) das calçadas dos bairros de Balneário Camboriú/SC, destacando que há situações críticas relacionadas 
à falta de pavimentação que impossibilita a circulação segura e autônoma (princípios básicos da acessibilidade) de moradores e turistas por esses locais. Destacam também a falta de rampas de acesso e ressaltam que "[...] devese prever a ampliação da acessibilidade no Centro, local em que se realiza o turismo religioso com o Congresso dos Gideões. Isso ampliaria a qualidade da infraestrutura do turismo, pois o centro é largamente apropriado por pedestres durante o referido evento" (Vieira \& Morastoni, 2013, p. 255).

Figura 2 - Composição de sinalização tátil de alerta e direcional no rebaixamento das calçadas-Exemplo

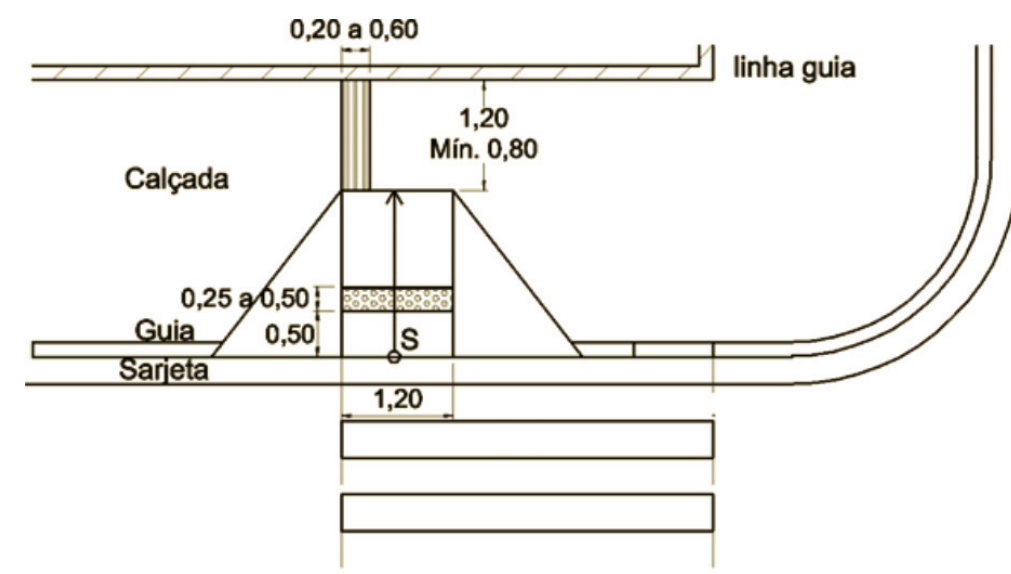

Vista superior

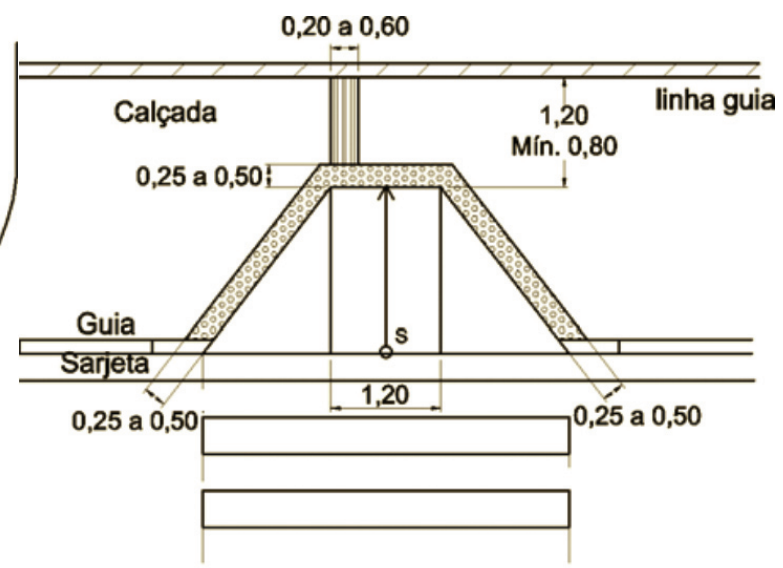

Vista superior

Fonte: NBR 9050, 2004, p. 36

Quando da adaptação em praias, o desnível entre o passeio e a areia deve ser realizado por meio de rampa, devidamente sinalizada com o Símbolo Internacional de Acesso, e estar vinculada a um piso fixo ou removível que se prolongue em direção ao mar, com no mínimo 0,90 m de largura.

A largura livre mínima recomendável para essas rampas é de 1,50 m, sendo o mínimo admissível 1,20 m, e sua inclinação entre 5\% e 8,33\%. No início e no término da rampa devem ser previstos patamares, juntamente com a sinalização tátil de alerta, com largura entre 0,25 m a 0,60 m, afastada de 0,32 m no máximo do ponto onde ocorre a mudança do plano (figura 3).

Os corrimãos devem ser instalados em ambos os lados das rampas a duas alturas: 0,70m e 0,92m, prolongando-se por pelo menos $30 \mathrm{~cm}$ antes do início e após o término sem interferir na circulação. Quando não houver paredes laterais, as rampas devem dispor de guarda-corpo associado ao corrimão e guias de balizamento instaladas nos limites da largura da rampa (figura 3). 
Figura 3 - Exemplo de inclinação transversal, largura de rampas e patamares das rampas
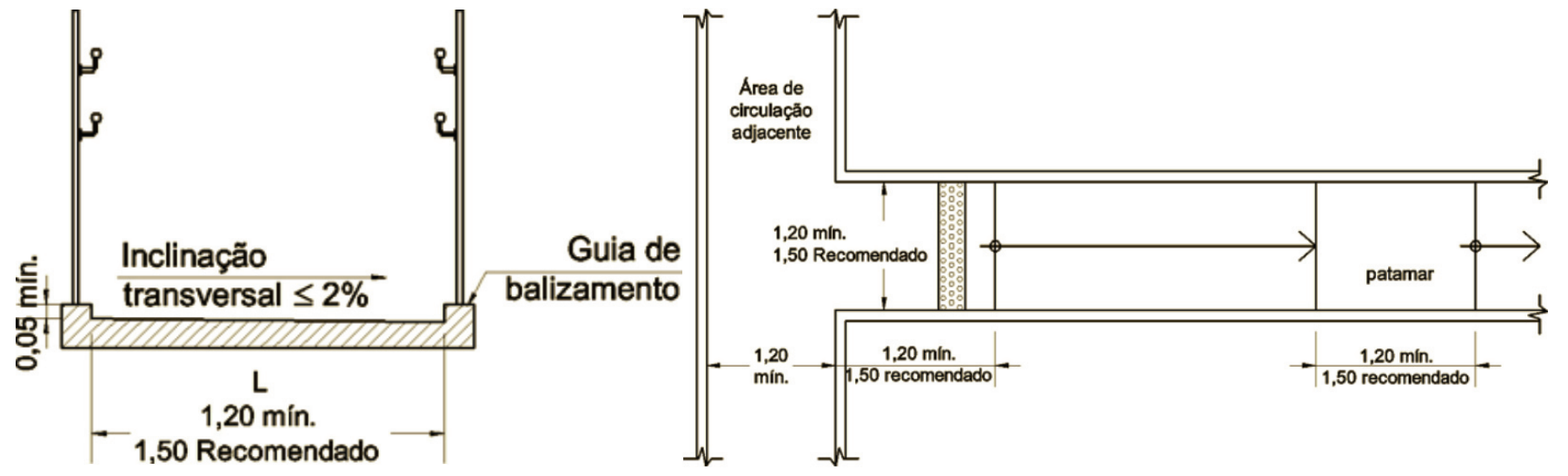

Fonte: NBR 9050, 2004, p. 43 e p. 44

Degraus e escadas fixas em rotas acessíveis devem estar associados à rampa ou ao equipamento de transporte vertical. A largura mínima recomendável para escadas fixas em rotas acessíveis é de 1,50 m, sendo o mínimo admissível $1,20 \mathrm{~m}$. O primeiro e o último degraus de um lance de escada devem estar no mínimo a 0,30 $\mathrm{m}$ da área de circulação adjacente e devem estar sinalizados com piso tátil de alerta, seguindo o padrão para rampas.

Os corrimãos devem ser instalados em ambos os lados dos degraus isolados e escadas fixas (figura 4). Quando não houver paredes laterais, as escadas devem dispor de guarda-corpo associado ao corrimão e guias de balizamento, instaladas nos limites da largura da rampa (figura 4).

Figura 4 - Exemplo de sinalização tátil de alerta nas escadas e guarda-corpo.
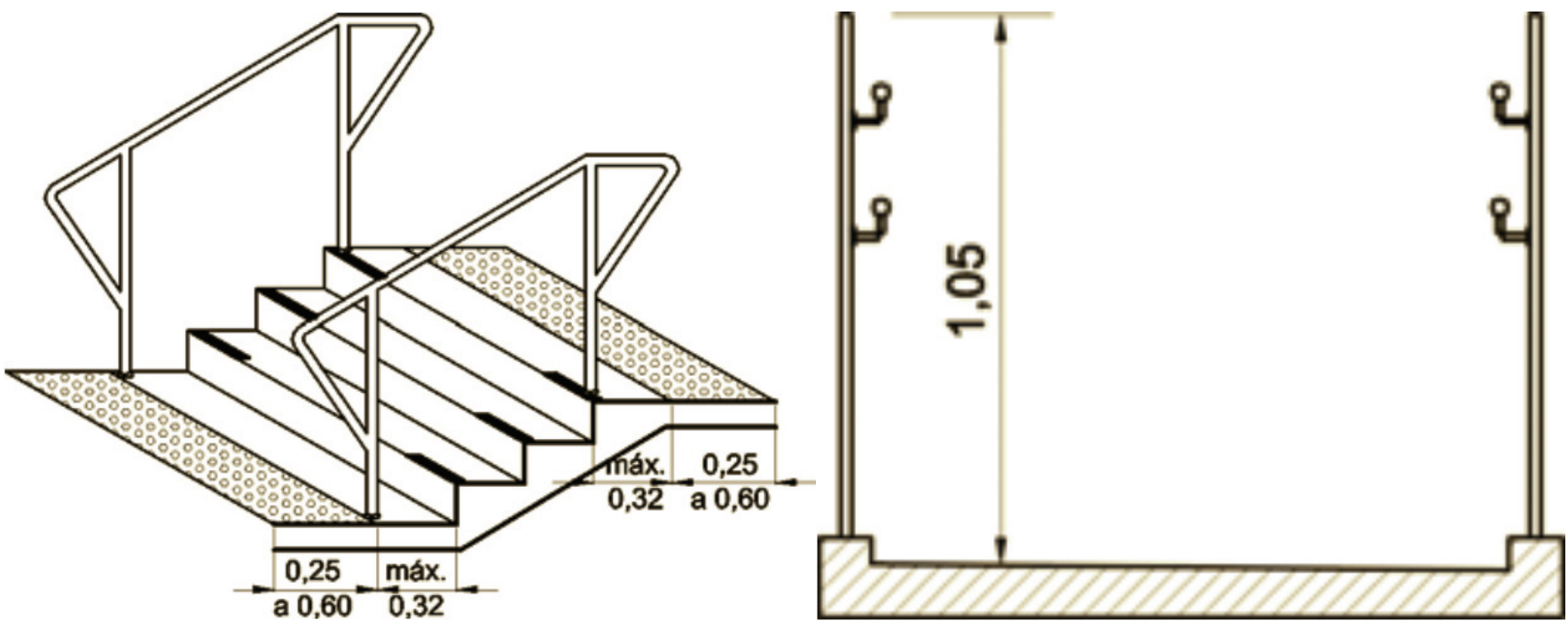

Fonte: NBR 9050, 2004, p. 32 e p. 90

Nas faixas de travessia, deve ser instalada a sinalização tátil de alerta no sentido perpendicular ao deslocamento à distância de 0,50 m do meio-fio. A 
sinalização tátil direcional é recomendada, no sentido do deslocamento, para que sirva de linha-guia, conectando um lado da calçada ao outro. A faixa elevada deve ser sinalizada com faixa de travessia de pedestres, sendo recomendada sua utilização em vias com largura inferior a $6 \mathrm{~m}$ ou travessias com fluxo de pedestre 5 vezes superior ao fluxo de carros (figura 5).

Figura 5 - Exemplo de rebaixamento de calçada e faixa elevada com sinalização tátil de alerta e direcional
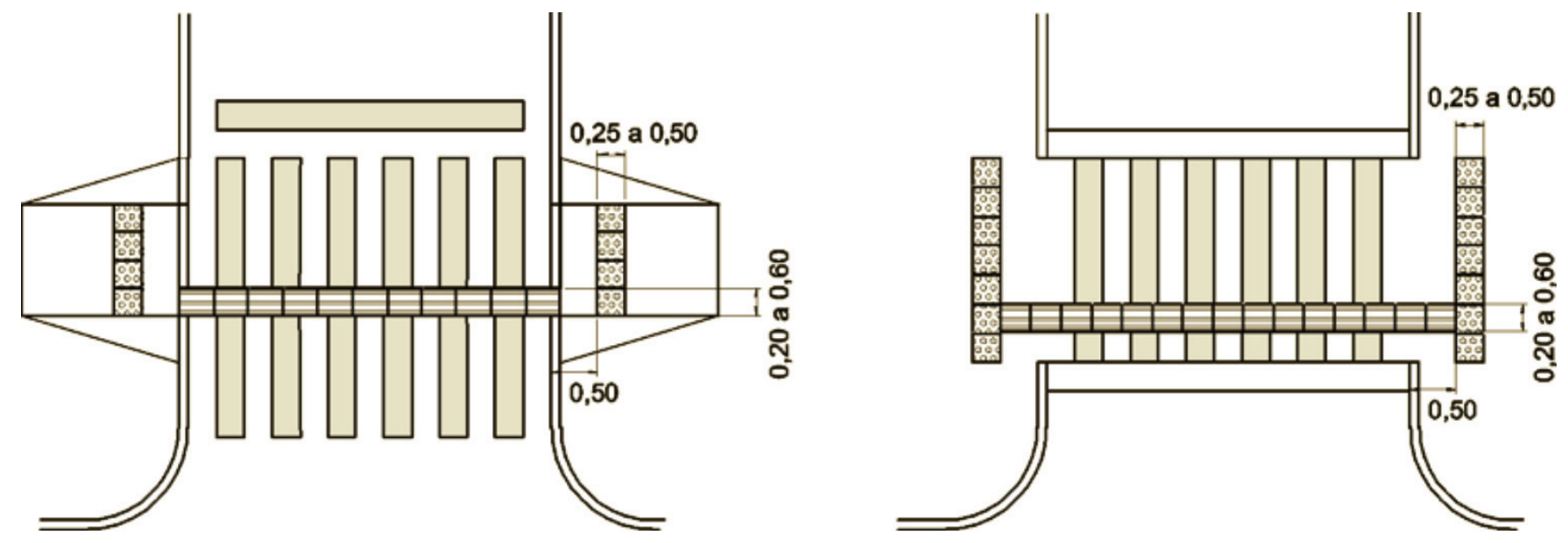

Fonte: NBR 9050, 2004, p. 37.

Em vias públicas com grande volume de tráfego, os semáforos devem estar equipados com mecanismos que emitam sinal sonoro associado e sincronizado aos alarmes visuais, de maneira a alertar as pessoas com deficiência visual e as pessoas com deficiência auditiva (surdez). Quando possuírem acionamento manual para travessia de pedestres, o dispositivo de acionamento deve situarse à altura entre $0,80 \mathrm{~m}$ e $1,20 \mathrm{~m}$ do piso.

Todos os telefones externos devem ser sinalizados com piso tátil de alerta excedendo em 0,60 m a projeção do obstáculo, em toda a superfície ou somente no perímetro desta. Pelo menos $5 \%$ do total dos telefones externos devem ser acessíveis para pessoa em cadeira de roda e outros $5 \%$ dispor de amplificador de sinal, possuindo indicação de acessibilidade através do Símbolo Internacional do Acesso ou de Pessoa com Deficiência Auditiva.

Figura 6 - Exemplo de sinalização tátil em obstáculos suspensos 


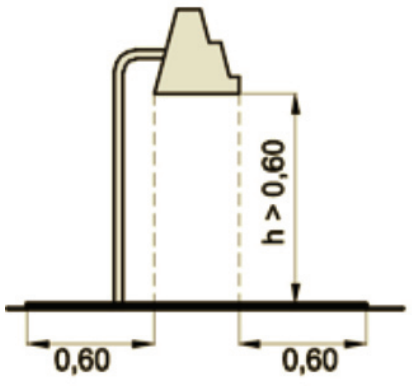

Vista lateral

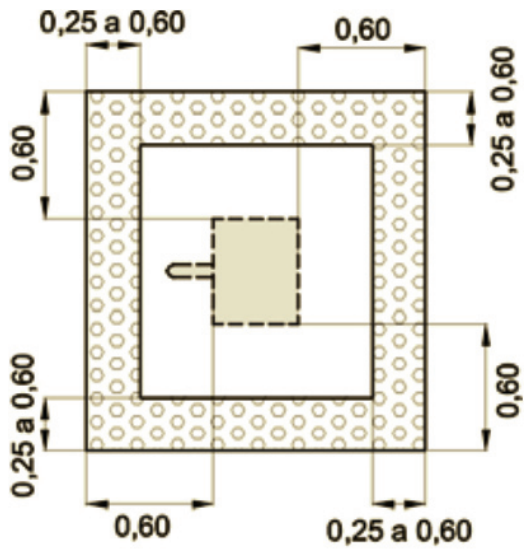

Planta

Fonte: NBR 9050, 2004, p. 31.

Os considerados acessíveis para pessoas em cadeiras de roda devem possuir medidas de: $1,20 \mathrm{~m}$ para a parte operacional superior; $0,73 \mathrm{~m}$ de altura livre do piso acabado; 0,75m de comprimento do fio; e altura livre da parte superior de proteção de $2,10 \mathrm{~m}$. Para chuveiros, os controles ou acionamentos devem estar localizados à altura entre 0,80 $\mathrm{m}$ e 1,20 m do piso, e quando acessíveis possuir indicação por meio do Símbolo Internacional do Acesso. Pelo menos $5 \%$ do total de assentos fixos ou bancos (figura 7) da rota devem ser previstos para acomodar pessoas com capacidade reduzida. Para tal, devem garantir um módulo de referência $(0,80 \mathrm{~m} \times 1,20 \mathrm{~m})$ ao lado do assento fixo, em posição que não interfira a faixa livre de circulação e indicar a acessibilidade por meio da aplicação do Símbolo Internacional do Acesso.

Figura 7 - Exemplo de banco

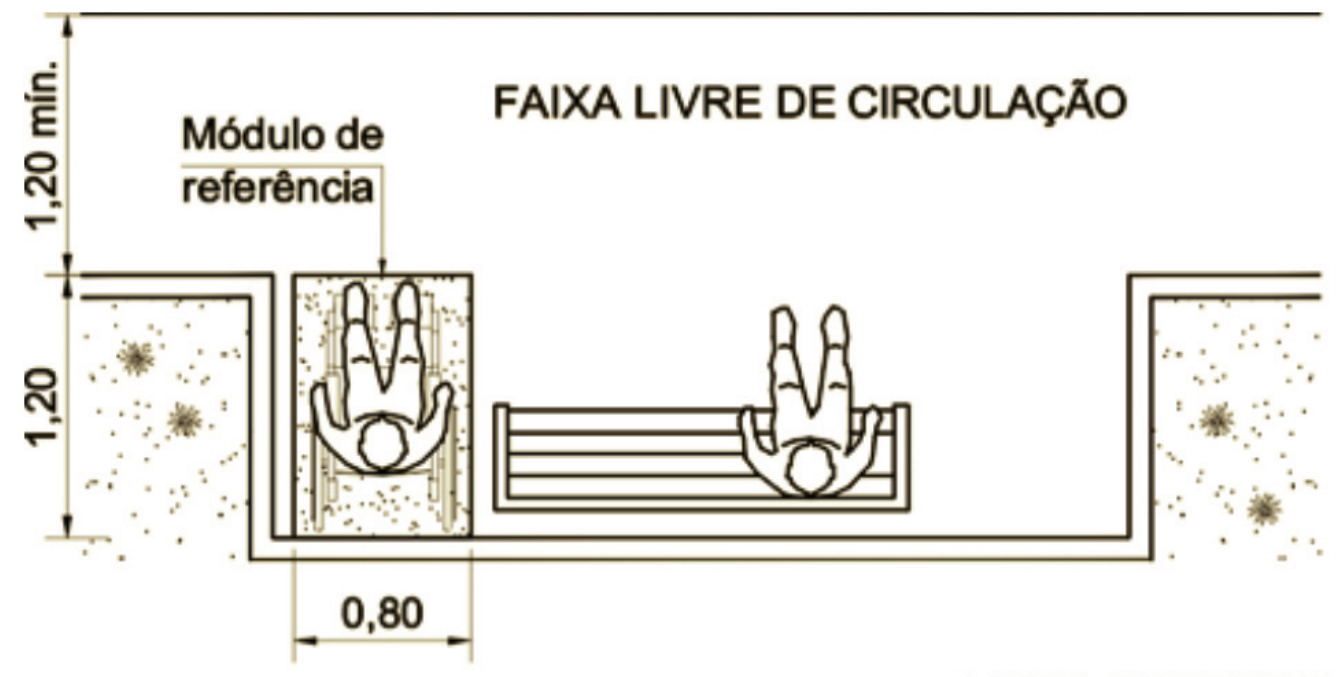

VISTA SUPERIOR

Fonte: NBR 9050, 2004, p. 93. 
As vagas para estacionamento destinadas a pessoas com deficiência devem possuir sinalização horizontal e vertical e quando afastadas da faixa de travessia de pedestres contar com um espaço adicional de circulação de no mínimo 1,20 $\mathrm{m}$ de largura que esteja associado à rampa de acesso à calçada.

Figura 8 - Sinalização horizontal de vagas e placa de regulamentação de estacionamento em via pública.

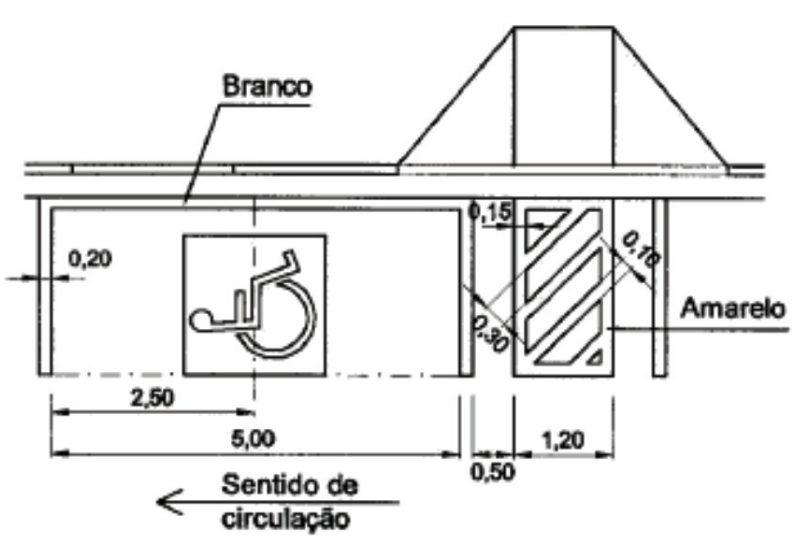

a) Paralela à calçada

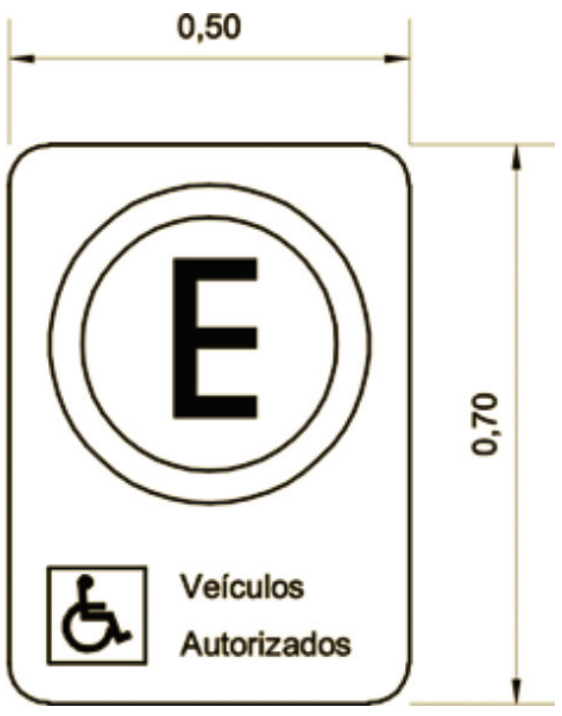

Fonte: NBR 9050, 2004, p. 61 e 62.

Para Grinover (2007), a acessibilidade, juntamente da legibilidade e da identidade, torna uma cidade hospitaleira, ou seja, acolhe o turista que a percorre pela primeira vez e o morador local. Sendo uma qualidade social, a hospitalidade implica uma organização dos lugares coletivos, juntamente com regras de uso, tal como o acesso a equipamentos, transportes e trabalho a todos os cidadãos. O território seria assim local democrático de reinvindicação da cidadania, buscando introduzir elementos caracterizadores da qualidade de vida e da inclusão social. Sendo assim, a correta execução dos elementos anteriormente citados e regulamentados pela NBR 9050 permite a padronização e a fácil leitura dos espaços acessíveis dentro de todas as cidades.

\section{O PROCESSO DE TRANSFORMAÇÃO DA ACESSIBILIDADE NA ÁREA CENTRAL DE BALNEÁRIO CAMBORIÚ}

Desde o início da história de Balneário Camboriú, o foco das transformações e reurbanizações da cidade ocorre em suas Avenidas arteriais. Dentro deste 
contexto, a área central da cidade abrange as Avenidas: Atlântica, Brasil, Terceira, Quarta, do Estado, Alvin Bauer e Central, a partir das quais se pode entender a evolução morfológica da cidade, juntamente coma a da acessibilidade.

Segundo Santos (2010), as Avenidas Atlântica e Brasil sofrerem revitalizações em 1990, quando seus passeios foram padronizados em petit-pavé nas cores branco e preto. Este material dificulta a locomoção de cadeirantes, pois devido a sua superfície irregular, gera trepidação e desgasta facilmente as cadeiras de roda, podendo até mesmo causar danos à saúde. Segundo o estudo realizado em 2010 por Santos, as calçadas, que já eram estreitas, eram prejudicadas ainda mais pela utilização de sua faixa de circulação por restaurantes e lojas. As rampas de acesso à praia eram totalmente inacessíveis, devido às inclinações acentuadas e à inexistência de guarda-corpos. Ao alcançar a areia, o cadeirante era impedido de chegar à água pela falta de piso, fixo ou removível, que permitisse o percurso da cadeira de rodas sobre a areia.

Na Avenida Central, o trecho que corresponde ao Calçadão foi construído em 1970 objetivando humanizar a área cujo fluxo de pedestres entre a praia e os comércios da Avenida Brasil, o qual era intenso, transformando-se assim em espaço público importante dentro da cidade. Além disso, não havia tratamento com arborização e, devido às várias entradas de garagens, os pedestres sofriam com a disputa por espaço com o automóvel, o que comprometia a acessibilidade, o conforto e a segurança. As Avenidas Terceira e Quarta, abertas entre 1960 e 1970, passaram por revitalizações de 2000 a 2002. Santos (2010) descreve ambas as Avenidas, no que corresponde ao período de 2010, como de mão dupla, duplicadas, e compostas por um canteiro central que abrigava a ciclovia. Esta estrutura física priorizava automóveis e ciclistas, visto que o fluxo da ciclovia interrompia o percurso do pedestre no ponto intermediário entre as pistas, causando insegurança e exigindo atenção redobrada. Ao mesmo tempo, as calçadas eram de blocos de concreto intertravados com a existência de pisos táteis, executados, porém, de maneira indevida, não sinalizando corretamente mobiliários e rampas.

A Avenida do Estado, que segundo os registros históricos, havia sido inaugurada em 1920, iniciou sua reurbanização em 2010, no trecho entre a 
Avenida Terceira e a Rua 1931. O resultado das obras não pôde ser verificado por Santos (2010), que realizou sua pesquisa durante a etapa de transformação da avenida, entretanto as obras previam, além de melhorias na infraestrutura urbana e no transporte, a padronização das calçadas considerando os conceitos de mobilidade urbana e de sinalização.

De modo geral, as ruas e os passeios da cidade foram identificados por Santos (2010) como inacessíveis para os cadeirantes, que tinham muitas vezes que transitar pelas faixas de rolamento devido aos obstáculos nas calçadas ou má conservação das mesmas, rampas com inclinações acentuadas, desníveis, bueiros ou mesmo a sua inexistência. Além disso, as calçadas estreitas, mesmo que dentro da largura mínima exigida, se tornam insuficientes, visto a grande quantidade de turistas que chegam à cidade nos meses de alta temporada. Para o deficiente visual, além destes problemas, a descontinuidade dos pisos táteis, assim como sua execução de maneira equivocada, prejudicava sua autonomia e independência, sendo muitas vezes impossível caminhar sem.

A partir da revisão do Plano Diretor em 2008, iniciaram-se a discussão e a determinação de diretrizes para melhoria da cidade: abertura de novas vias e prolongamentos viários, juntamente da requalificação urbana, buscando oferecer acessibilidade aos espaços públicos.

Portanto, dentro do que compõe o recorte físico da pesquisa, foram considerados para levantamento, mapeamento e análise de sua acessibilidade, os trechos reurbanizados dentro das Avenidas: Terceira, Quarta e do Estado, conforme o indicado pela Secretaria de Planejamento, e das Avenidas Atlântica e Brasil, de acordo com o identificado in loco, englobando as vias perpendiculares entre ambas, em razão da conexão que exercem e o alto fluxo de pedestres que suportam.

Após o levantamento de campo para viabilização do mapeamento da acessibilidade, a área identificada como de requalificação urbana recente foi dividida em nove trechos. Na figura 9 vê-se a divisão dos trechos junto de uma classificação conforme o nível de acessibilidade. Essa classificação é resultado da análise dos dados e será explicada a seguir.

Figura 9 - Mapa de reconhecimento das Áreas Requalificadas e Trechos 


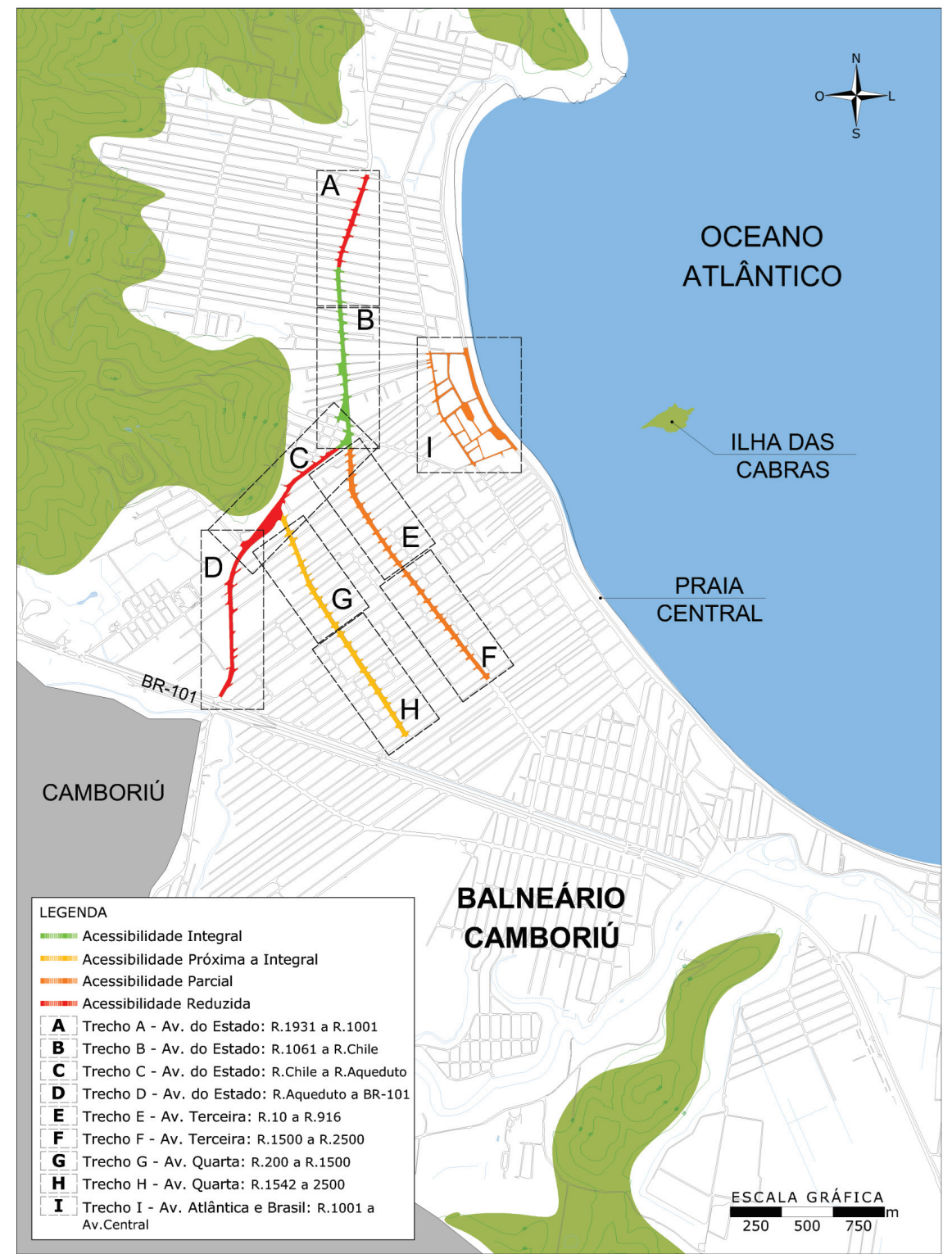

Fonte: Elaborada pelas Autoras, 2013.

\section{MAPEAMENTO E ANÁLISE DOS DADOS}

Para a verificação da acessibilidade, foi realizado um mapeamento dos trechos selecionados realizado por meio de pictogramas criados por Franzen (2014) e Franzen e Oliveira (2015), que naquela pesquisa representou a acessibilidade em três diferentes contextos: acessibilidade total, acessibilidade parcial e inacessibilidade. Neste estudo, foram utilizados os pictogramas de Franzen (2014, 2015), porém a acessibilidade foi classificada em: integral, próxima à integral, parcial e reduzida.

O trecho B e parte do trecho A (figura 13), que corresponde à Avenida do Estado entre a Rua 1001 e o encontro com a Avenida Terceira, foram classificados 
como de "Acessibilidade Integral" por permitirem o deslocamento autônomo e seguro para pessoas com mobilidade reduzida, e de maneira parcial para os deficientes visuais. Neste trecho as calçadas eram padronizadas em blocos de concreto intertravados, piso que possui superfície regular, facilitando o uso pelo cadeirante. Além disso, as larguras mínimas exigidas para os passeios estavam adequadas, e o piso tátil era contínuo por todo o trajeto (figura 11-foto 3).

Não existiam rebaixamentos de calçadas, todas as travessias possuíam faixas de pedestre elevadas, devidamente sinalizadas com piso tátil de alerta e direcional, o que eliminou todos os desníveis da área, com exceção da falha existente na Rua Espanha, onde não há nem rebaixamentos nem faixas elevadas. Dos nove semáforos existentes, seis possuíam sinalização visual para o pedestre (figura 11-foto 2), porém nenhum contava com a sinalização sonora, impedindo o deficiente visual de realizar as travessias com autonomia. Vagas de estacionamento acessíveis foram encontradas próximas aos bancos, possuindo acesso nivelado aos passeios e à sinalização adequada (figura 11-foto 4).

A deficiência do trecho em relação à acessibilidade é o mobiliário, nenhum dos bancos e orelhões encontrados no trecho estava adequado ao uso por uma pessoa com capacidade reduzida e não possuía sinalização tátil para identificação do deficiente visual, tornando-se barreiras para este usuário (figura 10-foto 1 ).

Figura 10- Caracterização da Acessibilidade - Avenida do Estado
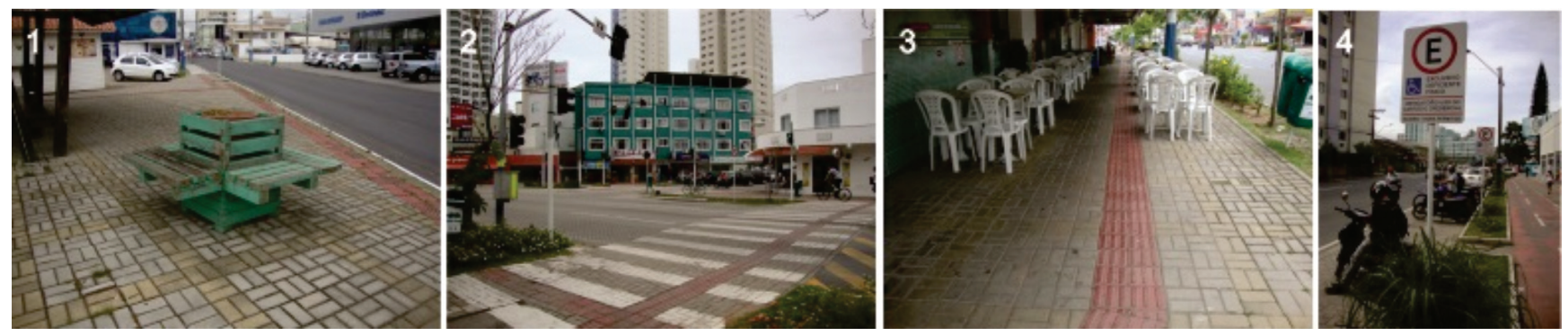

Fonte: Fotos e montagem elaborados pelas autoras, 2013.

Em contraste às condições de acessibilidade encontradas no trecho $B$ e parte do Trecho A, o restante da Avenida do Estado (figura 13 e 14) apresentase como trecho de acessibilidade reduzida, definida pela descontinuidade de seus elementos acessíveis, o que não proporciona autonomia e segurança ao deslocamento de pessoas com mobilidade reduzida ou deficiência visual. 
As calçadas não eram padronizadas. Foram encontrados piso petit-pavé, o qual gera trepidação para o cadeirante, não se adequando a uma rota acessível; trechos de calçada de concreto totalmente irregular (Figura 11-foto1); trechos de blocos de concreto intertravado (Figura 11-foto 2); e trechos de concreto alisado (Figura 11-foto 7). Apesar de em alguns trechos o piso estar adequado ao exigido, a descontinuidade elimina o conceito de uma rota acessível (Figura 11-foto 3). Além disto, o piso tátil era encontrado em pequenos trechos, sem conexão entre si e realizados de maneira equivocada (Figura 11-foto 4), o que impede o percurso autônomo para o deficiente visual.

Figura 11 - Caracterização da Acessibilidade - Avenida do Estado

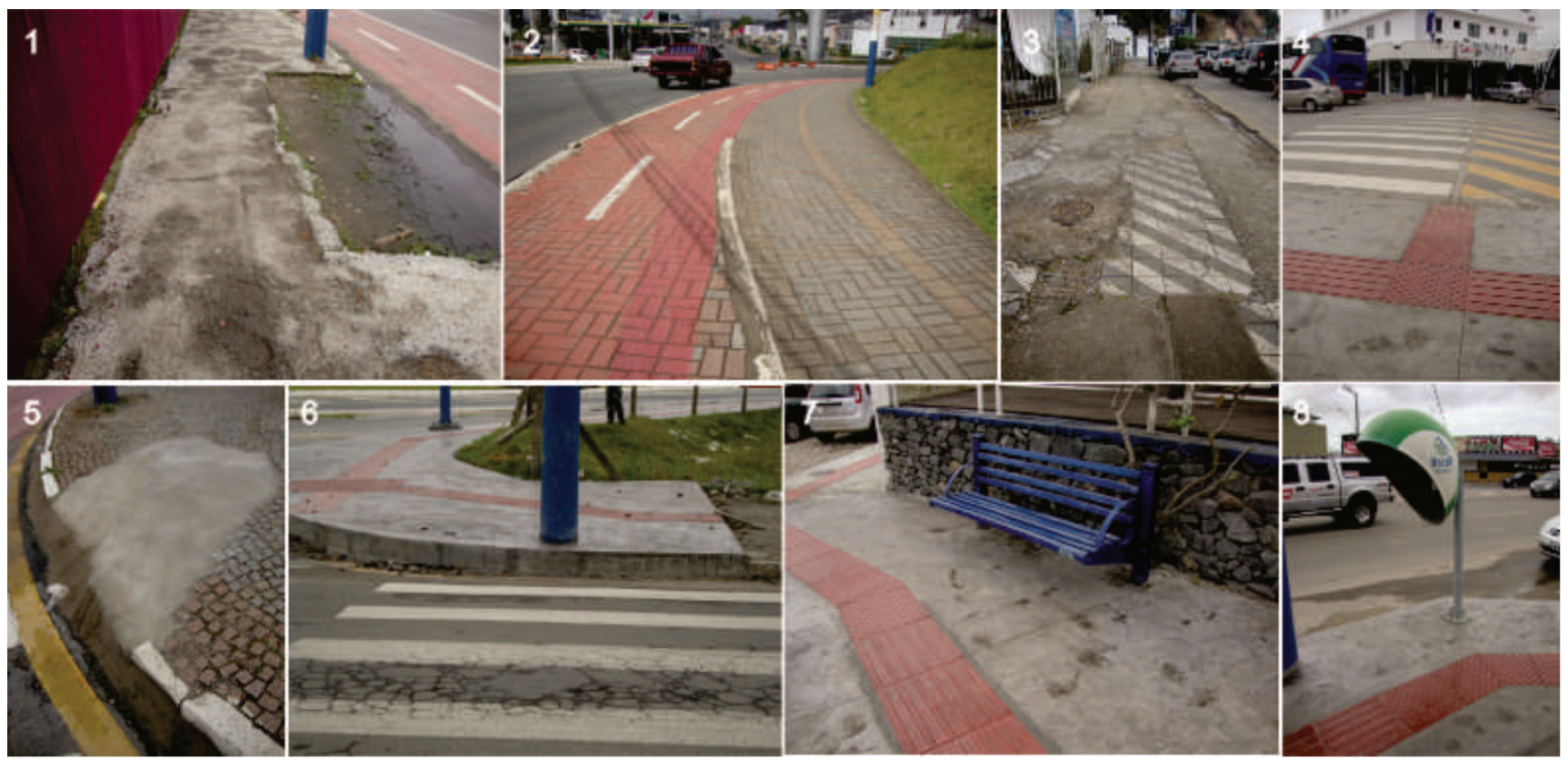

Fonte: Fotos e montagem elaboradas pelas autoras, 2013.

Os rebaixamentos de calçadas, assim como as faixas de pedestre, inexistiam em grande parte das travessias, gerando desníveis e impedindo o percurso para pessoa com capacidade reduzida (Figura 11-foto 6). Quando existentes, os rebaixamentos de calçadas estavam em total desacordo com a NBR 9050, apresentando desníveis em relação ao leito carroçável, sem sinalização com piso tátil de alerta, desalinhados em relação ao rebaixamento do lado oposto da via, terminando em bueiros ou mesmo com piso em condições precárias (Figura 11-foto 5).

Dos semáforos existentes, uma minoria apresentava sinalização visual para o pedestre e nenhum desses apresentava sinalização sonora para o deficiente 
visual. Não existiam vagas de estacionamento acessíveis e o mobiliário tampouco contemplava as exigências da Norma (Figura 11-foto 8), situando-se em locais de circulação, sem sinalização tátil, o que o configurava como barreira para o deficiente físico e visual.

Figuras 12 e 13 - Mapeamento da acessibilidade Trechos A e B, C e D.
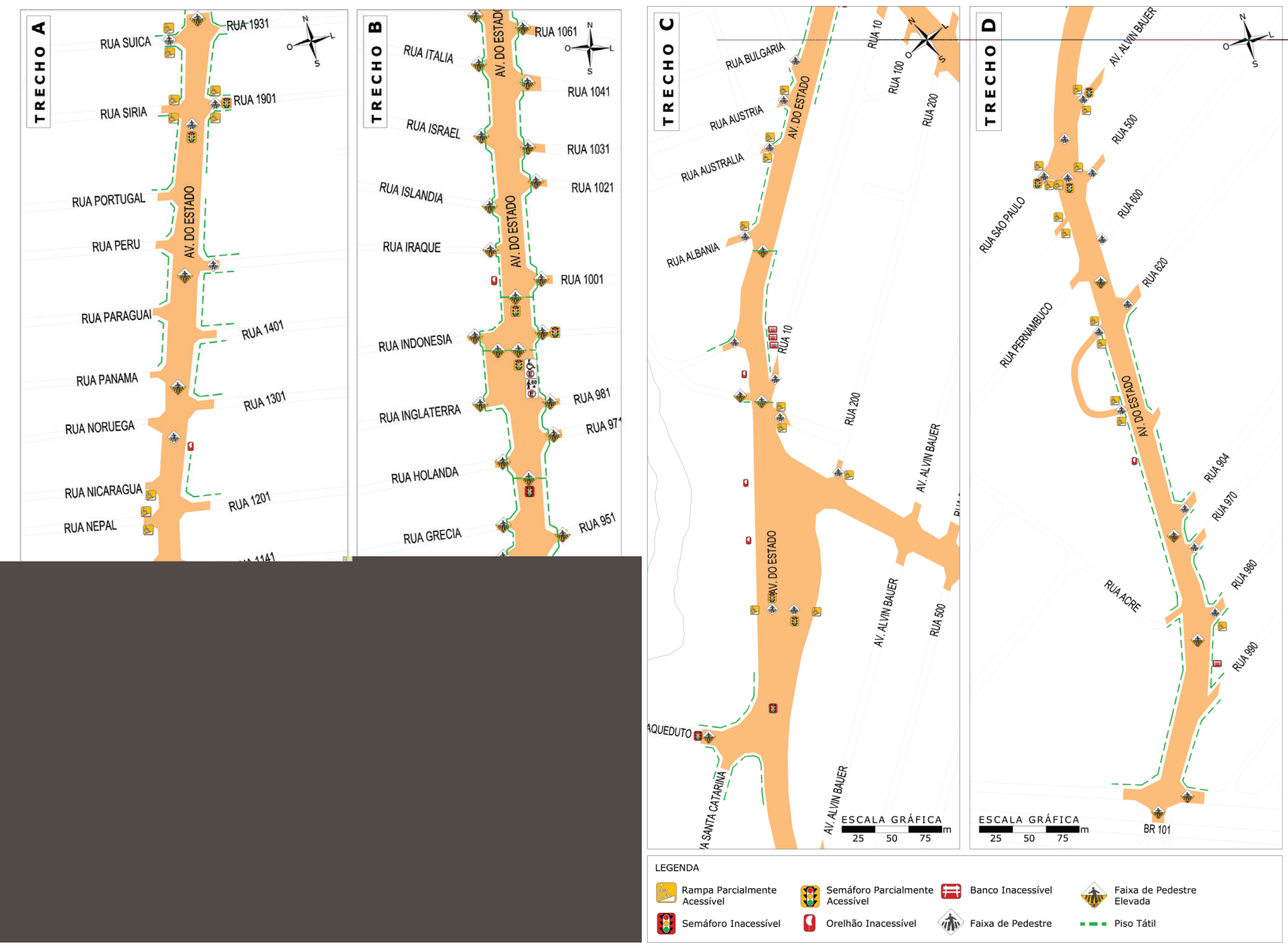

Fonte: Elaboradas pelas autoras, 2013.

\section{AVENIDA QUARTA: ACESSIBILIDADE PRÓXIMA À INTEGRAL}

Os trechos G e H (figura 15), que correspondem à Avenida Quarta, foram classificados como de "Acessibilidade próxima à Integral", por permitirem de maneira parcial o deslocamento autônomo e seguro para pessoas com mobilidade reduzida e deficiência visual.

As calçadas desta avenida foram padronizadas com piso de blocos de concreto intertravado, adequado para o deslocamento da cadeira de roda, além disso, se encontrava dentro da largura mínima permitida e possuía piso tátil em 
toda a sua extensão (figura 15-foto 3), com pequenas interrupções devido a tampas de caixas de inspeção ou obras inacabadas (figura 15-fotos 2 e 4).

Nas travessias entre um lado e outro da avenida foram implantadas faixas de pedestre elevadas, porém, nem todas eram sinalizadas com piso tátil de alerta e direcional. Para a realização da travessia nas vias perpendiculares à Avenida Quarta, a existência de faixas de pedestre e rebaixamentos de calçada ocorria em sua totalidade, porém nenhum dos rebaixamentos encontrava-se totalmente de acordo com a NBR 9050. Apesar de todos os rebaixamentos possuírem a sinalização tátil de alerta, em alguns casos tal sinalização estava executada de maneira equivocada, em outros havia desnível entre o fim do rebaixamento e o leito carroçável (figura 15-foto 1), ou a inclinação era superior a 8,33\%, fazendo-se necessário, por vezes, o auxílio à pessoa de mobilidade reduzida para transpor os rebaixamentos.

Vagas de estacionamento acessíveis foram encontradas próximas aos bancos e aos supermercados, não possuindo, entretanto, o espaço adicional de circulação, somente eram indicadas por meio da sinalização vertical. Apesar da continuidade do piso tátil direcional, os mobiliários, além de todas as características anteriormente elencadas que os tornam inacessíveis, não eram sinalizados com piso tátil de alerta, tampouco os semáforos apresentavam sinalização visual ou sonora para o pedestre, o que limita o percurso autônomo para o deficiente visual.

Figura 15 - Caracterização da Acessibilidade - Quarta Avenida

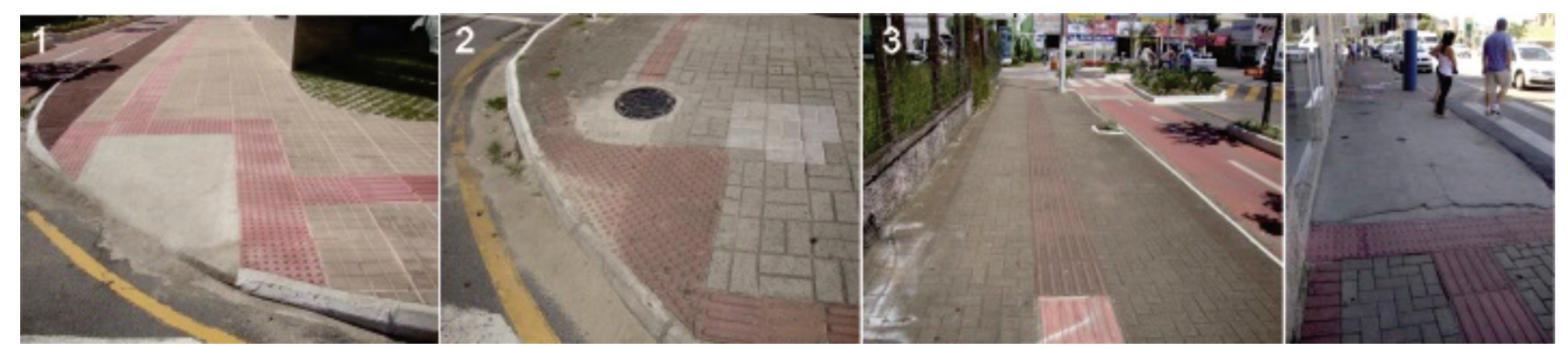

Fonte: Fotos e montagem elaboradas pelas autoras, 2013.

Figura 16 - Mapeamento da acessibilidade Trechos G e H 


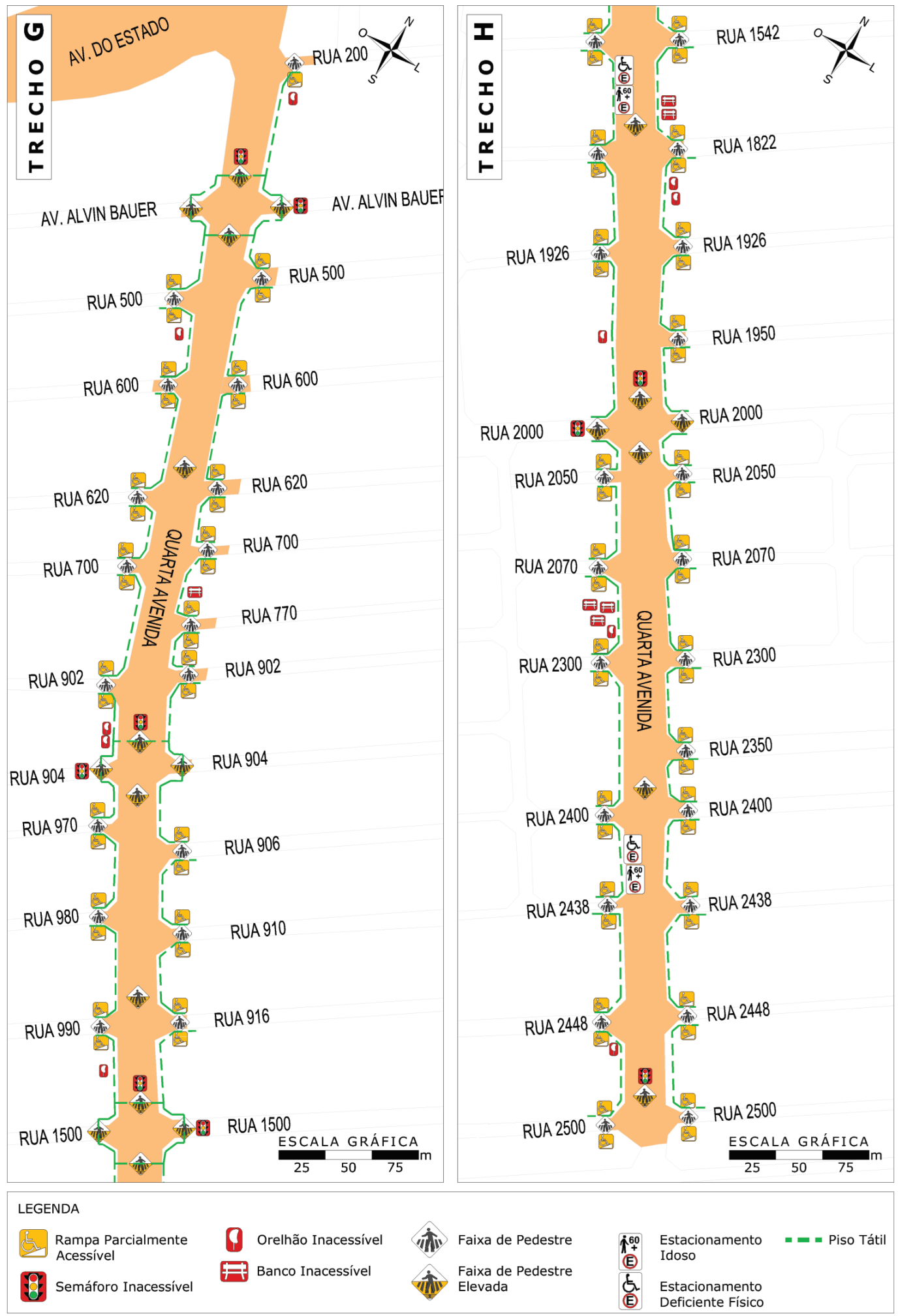

Fonte: Elaborada pelas autoras, 2013.

Os trechos E e F (figura 18), que correspondem à Avenida Terceira, foram classificados como "Acessibilidade Parcial", por permitirem de maneira parcial o deslocamento autônomo para pessoas com mobilidade reduzida e não o permitirem para o deficiente visual. As calçadas da Avenida Terceira estavam de acordo com a largura mínima exigida pela NBR 9050 e eram padronizadas em piso de blocos de concreto intertravado, adequadas para o deslocamento do 
cadeirante. Porém alguns trechos encontravam-se em mau estado de conservação, apresentando buracos ou até mesmo desníveis em relação às edificações (Figura 17-fotos 1 e 2), o que dificulta o trajeto a pessoas de capacidade reduzida.

Todas as vias apresentavam faixas de pedestre e rebaixamento das calçadas, ou faixas de pedestre elevadas para realização de sua travessia. Os rebaixamentos, apesar de existentes na totalidade do percurso, não estavam totalmente de acordo com a NBR 9050, possuíam desníveis em relação ao leito carroçável, inexistência de piso alerta ou execução inadequada, bueiros e buracos no piso (Figura 17-foto 5), fazendo-se necessário, em alguns casos, o auxílio à pessoa com mobilidade reduzida para transpor o rebaixamento.

As faixas de pedestre elevadas foram executadas ao longo da Avenida para realizar a travessia entre um lado e outro da mesma, e em vias perpendiculares quando de importante fluxo. Nesses pontos, de cruzamento entre vias de fluxo intenso, o piso tátil foi executado em pequenos trechos de maneira desconexa (Figura 17-fotos 3 e 4); juntamente, os semáforos não possuíam sinalização visual ou sonora para o pedestre (Figura 17-foto 6), e o mobiliário se tornava barreira (Figura 17-fotos 7 e 8), por não possuir a sinalização tátil de alerta e se encontrar dentro das faixas de circulação, o que impede o deslocamento autônomo do deficiente visual.

Figura 17 - Caracterização da Acessibilidade - Terceira Avenida

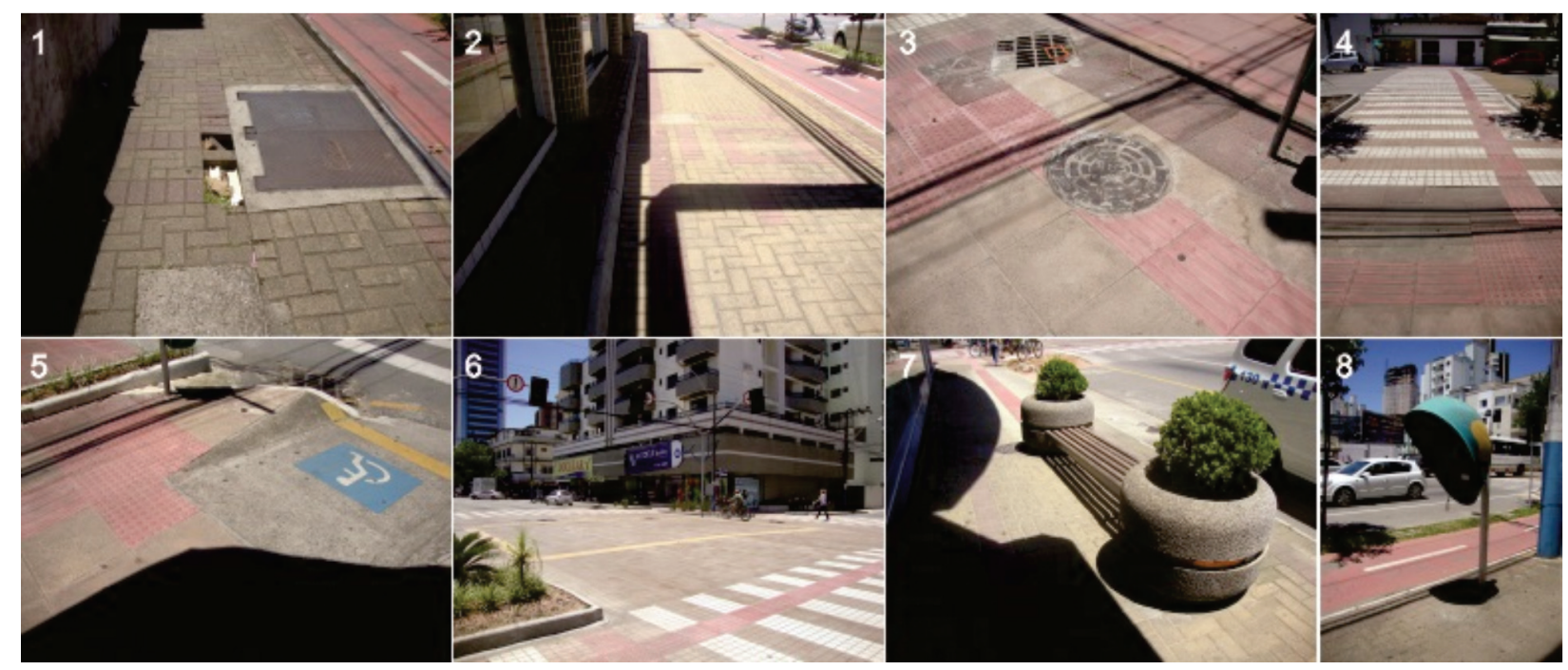

Fonte: Fotos e montagem elaboradas pelas autoras, 2013.

Figura 18 - Mapeamento Acessibilidade Trechos E e F 


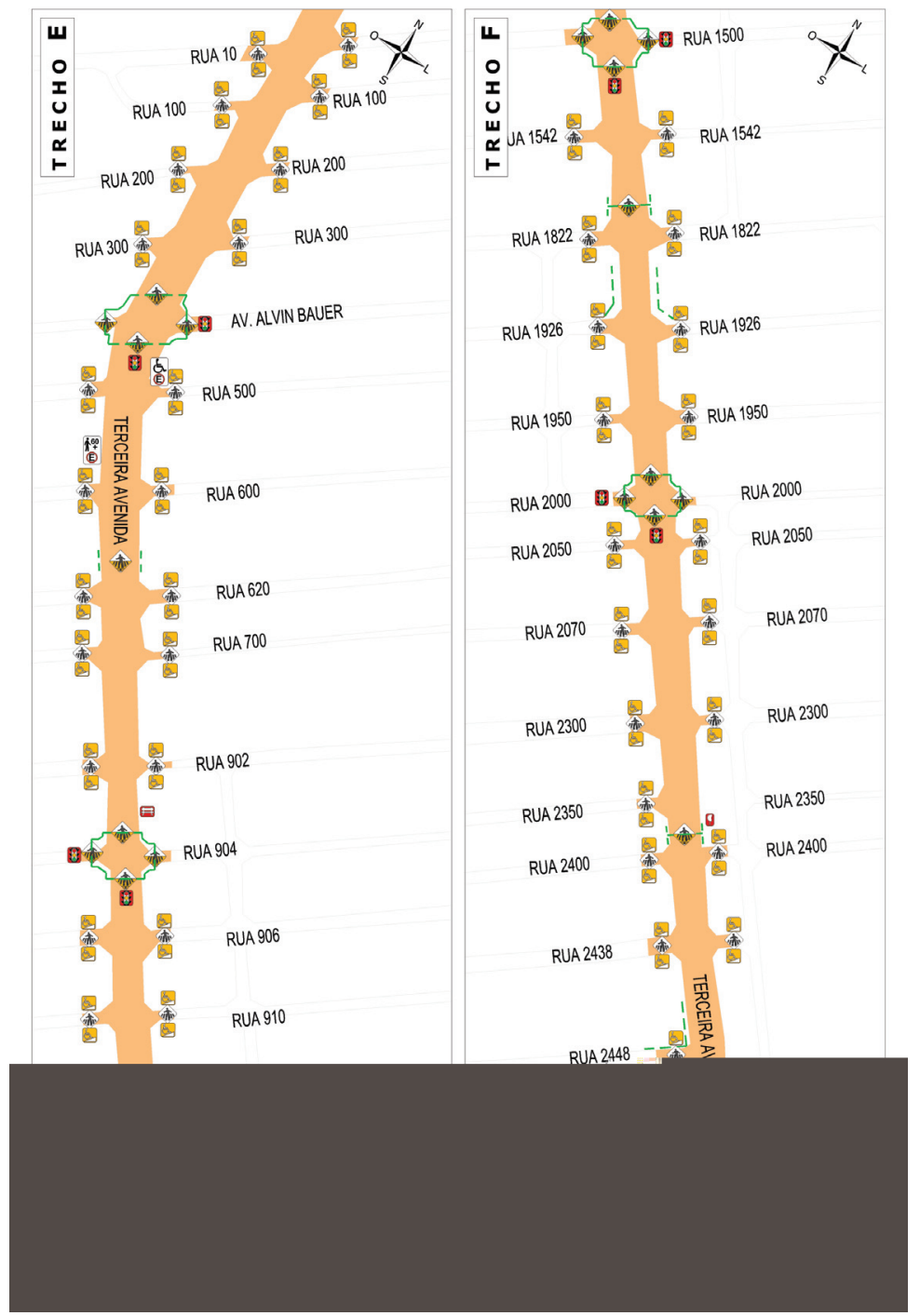

Fonte: Elaborada pelas autoras, 2013.

O trecho I (figura 20), que corresponde às Avenidas Atlântica e Brasil, é considerado um dos trechos com maior circulação de turistas na cidade de Balneário Camboriú, visto que neste trecho está localizada a Praça Almirante Tamandaré, Praça Higino João Pio, Praia Central, além da maior concentração de meios de hospedagem da cidade, dessa forma, caracteriza-se como um espaço turístico, por causa dos atrativos turísticos (praia e praças) e da infraestrutura turística e básica. O trecho I foi classificado como "Acessibilidade Parcial", por permitir o deslocamento autônomo e seguro para pessoas com mobilidade reduzida e de maneira parcial para o deficiente visual, em parte do trajeto.

Nas calçadas, o piso petit-pavé, padronizado na reurbanização anterior, em 1990, por toda a extensão da Avenida Atlântica, segue como piso padrão para a área. Na Praça Higino João Pio, alguns trechos da Avenida Brasil e nas vias transversais, o piso também é encontrado, apesar de gerar trepidações e dificultar o percurso ao cadeirante. Na Avenida Central, Avenida da Lagoa, e parte da 
Avenida Brasil, que correspondem aos cruzamentos com a Rua 511 e Avenida Alvin Bauer, o piso passou a ser de concreto, o que facilita a locomoção.

Nestes trechos isolados, juntamente com a mudança do piso foram instaladas faixas de pedestre elevadas, eliminando desníveis, pisos táteis de alerta e direcional para as travessias, porém sem sinalização do mobiliário, e semáforos com sinalização visual para o pedestre, porém, sem sinalização sonora, o que impede a travessia autônoma para o deficiente visual. Na Rua 511, em frente ao shopping estão as vagas de estacionamento para o deficiente físico e o idoso. Considerados de forma isolada estes pequenos trechos configuram-se, de certa maneira, como acessíveis. Entretanto, a descontinuidade do trajeto e as condições encontradas nas demais áreas do trecho, principalmente em suas transversais e no acesso à praia (figura19-foto5) tornam a rota inacessível.

Em relação ao mobiliário, bancos e orelhões estavam em desacordo com as exigências para a acessibilidade (figura 19-fotos 7 e 8). Em muitas vezes, lixeiras situadas ao lado dos bancos impediam até mesmo que o cadeirante se sentasse ao lado de outro usuário que o estivesse utilizando-o (figura 19-foto 6). Além disso, o mobiliário não recebia sinalização tátil de alerta, representando uma barreira para o deficiente visual.

Os acionamentos de todos os chuveiros estavam localizados a 1,50m do piso, impedindo que um cadeirante o acionasse. Em alguns casos, mesmo auxiliado por outra pessoa, esse usuário não conseguiria se aproximar devido a contenções para a água que se configuravam como barreiras (figura 19-fotos 2 e 4).

Figura 19 - Caracterização da Acessibilidade - Avenidas Atlântica e Brasil

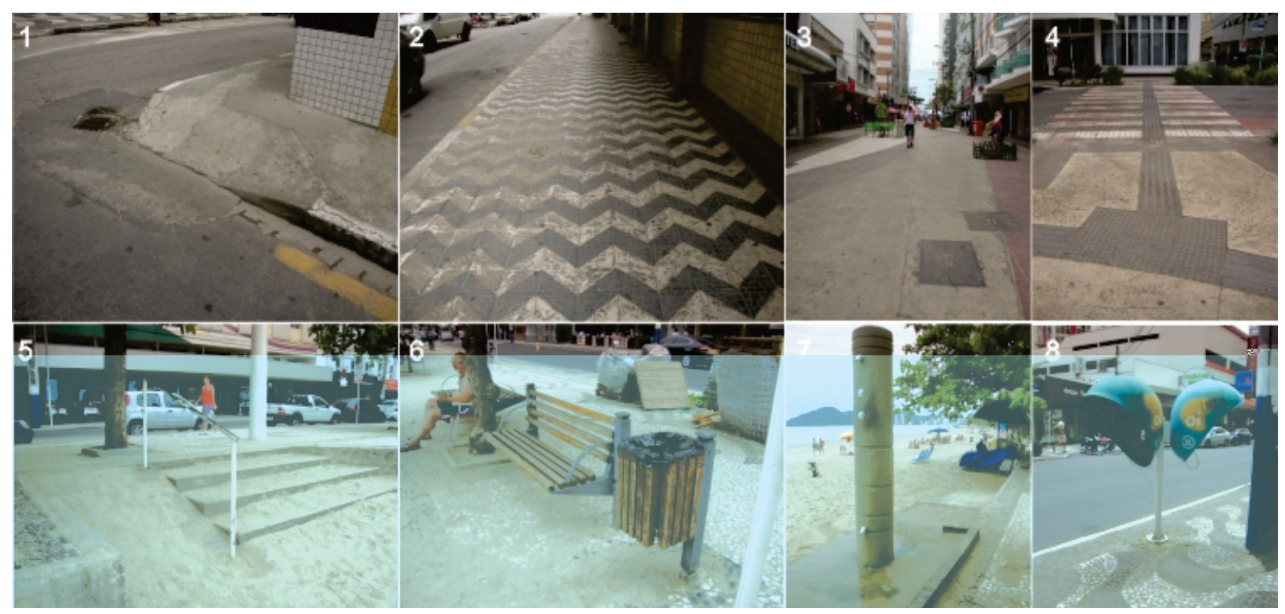

Fonte: Fotos e montagem elaboradas pela autora, 2013. 
No restante da área, as travessias eram compostas por faixas de pedestre e rebaixamentos das calçadas, sendo que além de serem inexistentes em algumas ruas, gerando desníveis entre passeio e leito carroçável, tais rebaixamentos não estavam adequados segundo a NBR 9050. A falta de sinalização tátil de alerta, desníveis, inclinações acima dos 8,33\%, juntamente de bueiros e buracos fazia com que o auxilio à pessoa com capacidade reduzida fosse necessário. Nas ruas transversais às Avenidas encontravam-se calçadas com largura inferior a mínima exigida pela norma, o que tornava as ruas que permitem o acesso à praia totalmente inacessíveis, com exceção da Avenida Central.

Ao analisarmos o espaço turístico composto pela orla da Praia Central, notase que o mesmo é inacessível ao deficiente físico e visual, pois, não permite que estes usuários desfrutem e o acessem de maneira segura, autônoma e inclusiva. As rampas e escadas de acesso à praia não possuíam sinalização tátil, visual, guarda-corpos e por vezes nem mesmo corrimões. A inclinação elevada das rampas as tornavam inutilizáveis mesmo para uma pessoa em condições normais. Ao chegar a areia, o percurso até o mar não era tratado com nenhum tipo de piso que permitisse ao cadeirante utilizar o espaço público da praia, excluindo-o deste espaço turístico e do convívio em sociedade.

Figura 20 - Mapeamento Acessibilidade Trecho I

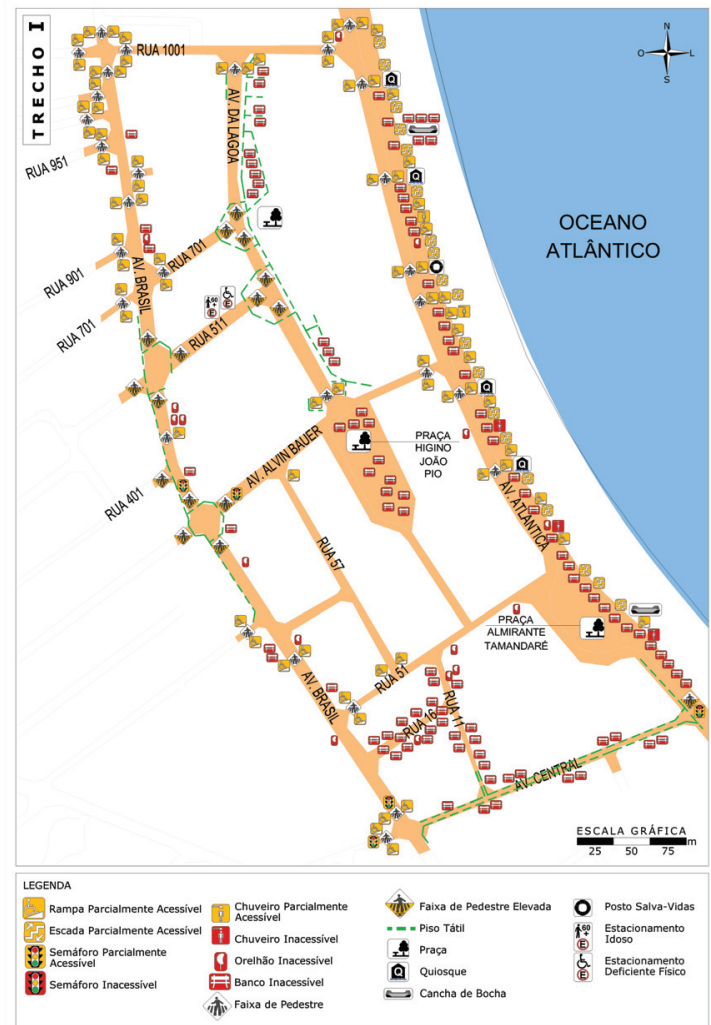

Fonte: Elaborada pela autora 2013. 


\section{CONSIDERAÇÕES FINAIS}

Com base nos resultados dessa pesquisa, apreende-se que o espaço da cidade de Balneário Camboriú, que sofreu requalificações entre 2010 e 2013, ainda não se configura como uma rota acessível para a pessoa com mobilidade reduzida (NBR 9050, 2004). Mesmo que em trechos isolados, a locomoção de maneira autônoma para o cadeirante é possível. Entretanto, para o deficiente visual tal independência é barrada pela falta de acessibilidade. O uso de mobiliários como bancos e orelhões é dificultado para ambos, segregando-os de atividades de convívio e comunicação. A definição de espaço como representação de uma sociedade (Gayer, 2006) atenta para as transformações do espaço urbano de Balneário Camboriú como representativo da evolução de sua sociedade. As requalificações recentes, que buscavam espaços acessíveis, revelam a intenção de inserir e gerar qualidade de vida para as pessoas com capacidade reduzida em uma sociedade igualitária. Apesar desta intenção, a inclusão deste cidadão na sociedade de Balneário Camboriú ainda está em processo, classificando-se como em fase de integração (Sassaki, 2007), pois cabe à pessoa com deficiência se adaptar aos espaços públicos da cidade, tendo em vista que o espaço não é totalmente acessível a ela.

O espaço público, e principalmente o espaço turístico urbano (trecho I) de Balneário Camboriú, não cumpre com o requisito acessibilidade, podendo ser apreendida como não hospitaleira quando esse for analisado de maneira isolada. Com destaque para a Praia Central, onde o principal atrativo turístico da cidade (areia e oceano) não pode ser acessado conforme o padrão normativo, segregando, assim, o turista com capacidade reduzida das atividades desse espaço, fator motivador de sua viagem.

Tendo em vista que muitas cidades perdem turistas, devido à falta da infraestrutura de acessibilidade (Bullón, 2002), adotar os padrões sugeridos pela NBR 9050 deveria ser visado não somente como uma necessidade social, mas, sobretudo, como um investimento turístico e econômico. Uma vez que os passeios e, consequentemente, os mobiliários inseridos na cidade, configuram seu espaço público, permitindo o convívio e a interação, para alcançar sua 
plena acessibilidade, a total responsabilidade por esses elementos deveria ser incumbida aos órgãos de poder público, para que esses gerissem não só a fiscalização e a padronização, senão a completa e correta execução, para que em prol do bem comum nossa cidade se adeque a todos os cidadãos.

\section{REFERÊNCIAS}

Associação Brasileira de Normas Técnicas. (2004) NBR 9050: Acessibilidade a edificações, mobiliário, espaços e equipamentos urbanos. Rio de Janeiro.

Alberti, M. (2005) The effects of urban patterns on ecosystem function. International Regional Science Review. Sage Publications, 28(2), p.168-192. Recuperado em 05 maio, 2012 de http:// irx.sagepub.com/content/28/2/168.abstract.

Brasil. Ministério do Turismo. (2013) Índice de Competitividade do turismo nacional: destinos indutores do turismo regional. Brasília, DF, 2013.

Boullón, R. C. (2005) Os municípios turísticos. Bauru, SP: EDUSC.

Boullón, R. C. (2002) Planejamento do Espaço Turístico. Bauru, SP: EDUSC.

Dias, R. (2005) Segmentação do mercado Turístico. Introdução ao Turismo. São Paulo, SP: Editora Atlas.

Franzen, L. I. .(2014) Hospitalidade pública: um estudo sobre a acessibilidade nos espaços turísticos de Balneário Camboriú/SC direcionada a pessoas com mobilidade reduzida e com deficiência Dissertação (Mestrado em Turismo e Hotelaria), Universidade do Vale do Itajaí, Balneário Camboriú, Santa Catarina, Brasil.

Franzen, L. I., \& Oliveira, J. P. (2015) Acessibilidade em destinos turísticos: criação de pictogramas para mapeamento. In: XI SEMINÁRIO DA ASSOCIAÇÃO NACIONAL PESQUISA E PÓS-GRADUAÇÃO EM TURISMO, 11., 2015, Caxias do Sul. Anais... Natal: UFRN, 2015. p. 1-13

Gayer, P. A (2006) Leitura Turística Do Espaço Urbano. In: SEMINÁRIO DE PESQUISA EM TURISMO DO MERCOSUL, 6., 2006, Caxias do Sul. Anais... Caxias do Sul: UCS, 2006. p. 1-15.

Grinover, L (2007) A hospitalidade, a cidade e o turismo. São Paulo: Aleph.

Ruschmann, D. M. (1997) Turismo e planejamento sustentável: a proteção do meio ambiente. Campinas, SP: Papirus.

Santos, M. (1997) O espaço do cidadão (3a ed) São Paulo: Nobel. 
Santos, D. H. (2010) Acessibilidade para pedestres com deficiência em espaços turísticos urbanos: a situação da área central de Balneário Camboriú (SC). Dissertação (Mestrado em Turismo e Hotelaria), Universidade do Vale do Itajaí, Balneário Camboriú, Santa Catarina, Brasil.

Santos Júnior, A. (2012) A pessoa idosa no turismo de praia: algumas considerações. In: RUSCHMANN. D. M.; SOLHA, K. T. (org.) Turismo e lazer para a pessoa idosa. Barueri, SP: Manole.

Sassaki, R. K. (1997) Inclusão: construindo uma sociedade para todos. Rio de Janeiro, RJ: WVA.

Silva, Y. E., \& Boia, Y. I. K. (2006) Turismo e responsabilidade social - uma reflexão sobre os direitos das pessoas com necessidades especiais. In: Ruschmann. D. M., \& Solha, K. T. (org.). Planejamento Turístico. Barueri, SP: Manole.

Vieira, R., \& Morastoni, R. (2013) Qualidade das calçadas na cidade de Camboriú/SC: em busca da acessibilidade e mobilidade sustentável para área turística. Revista Brasileira de Pesquisa em Turismo. São Paulo, 239-259. 